\title{
Philosophy's attitude towards the comic. A re-evaluation
}

\author{
Lydia B. Amir \\ College of Management Academic Studies, Rishon LeZion, Israel
}

\begin{abstract}
Contrary to common opinion, philosophy's relations with the comic are profound and complex, yet the nature and significance of this relationship is surprisingly understudied. I have found that the relations that philosophy entertains with the comic can be conceptualised in ten traditions, eight dating from antiquity and two from modern and postmodern times. I trace these traditions from antiquity through the Middle Ages, the Renaissance and modern times. I explain how the view that philosophy is inimical to the comic originated and invite the reader to re-evaluate philosophy's attitude towards the comic.
\end{abstract}

Keywords: philosophy, history, the comic.

\section{Introduction}

In this article I challenge the accepted view of philosophy as inimical to the comic. I argue that it originated in two ancient traditions of laughter, namely, the Laughless (agelastos) Philosopher and the Mocking Sophist. The former tradition, which begins with Pythagoras in the $6^{\text {th }}$ to $5^{\text {th }}$ century B.C., features the philosopher as a being that never laughs because he is too preoccupied with lofty ideas to be engaged in such an earthly matter. The latter tradition, beginning with Gorgias the Sophist in the $5^{\text {th }}$ century B.C. and recorded by Aristotle, recommends laughter as a rhetorical device to destroy the opponent's argument, and has led to a whole branch of Greco-Roman rhetoric. Philosophy's devaluation of rhetoric led to its differentiation from the tradition of the Mocking Sophist; at the same time, the tradition of the Laughless Philosopher gained followers; together these traditions account for the image of philosophy as devoid of the comic.

A thorough study of the relation of philosophy with the comic, however, reveals it as more complex than the relation disclosed by these traditions. I have found six additional ancient traditions of the comic, that, unfolding through the Middle Ages and flourishing in the Renaissance, are rediscovered in modern times, as well as two further traditions that originate in modern times. They are: 
1. The Ridiculous Philosopher: beginning with Thales ( $6^{\text {th }}$ century B.C.), this tradition views the philosopher or philosophy as laughable to society, and later, as laughable both to theologians and those philosophers who prioritise practice over theory.

2. The Laughing Philosopher: beginning with Democritus $\left(5^{\text {th }}\right.$ century B.C. $)$, this tradition features philosophers whose final judgment on life is expressed in laughter. In addition to Democritus, whom the legend portrays as laughing, Michel de Montaigne, Thomas More, Friedrich Nietzsche, and George Santayana are recognized as laughing philosophers.

3. The Comical Philosopher: epitomized in Socrates ( $5^{\text {th }}$ century B.C.), this tradition features the archetype of the teacher, the embodiment of philosophy, as both a laughing and laughable person. Socrates uses a paradoxical duality as a tool for teaching philosophy. This method is expressed in an inextricable connection between the serious and the ridiculous or between the sublime and the low.

4. Philosophy is Comedic: both for Plato and the Cynics ( $5^{\text {th }}$ century B.C.), the comical fulfils such an important role in philosophy that the practice of philosophy is compared to comedy. Laughter in various forms (irony, wit, sarcasm, humour) is an important means for conveying philosophical ideas that seem paradoxical and are at odds with society's values, as well as for attracting attention, overcoming resistance, and prompting change in listeners or readers by enabling them to contemplate both sets of values-society's and philosophy's-with the quick cognitive shifts and reduced anxiety levels produced by laughter. With the Cynics' influence on all Hellenistic schools, and the later influence of these schools on the Renaissance and the Enlightenment, the serio-comic becomes the main form of exoteric writing in philosophy.

5. Wit is a Virtue: beginning with Aristotle $\left(4^{\text {th }}\right.$ century B.C.), this tradition maintains that laughter used correctly and for the right purposes is a virtue, thereby making laughter a part of the good life.

6. Laughter is the Mark of the Human: originating in a mistaken attribution to Aristotle, this tradition emphasizes philosophy's special interest in laughter. Laughter reveals the essence of the human, either by its affinity with the rational, or otherwise. The popular view that the human being is the only animal that laughs (homo ridens) is later complemented by the less common view of the human being as the laughable animal (homo risibilis).

7. Laughter is Epistemologically Valuable: originating with the third Earl of Shaftesbury $\left(18^{\text {th }}\right.$ century), this tradition recognizes an epistemological value in laughter, as laughter helps us grasp the truth.

8. Laughter is Ontologically Rooted: George Santayana in the English speaking world $\left(19^{\text {th }}-\right.$ $20^{\text {th }}$ century) and Clément Rosset in the French speaking world ( $20^{\text {th }}$ century) are at the forefront of a tradition that views laughter as ontologically rooted inasmuch as reality itself is comical [1].

I trace these traditions from antiquity through the Middle Ages, the Renaissance and modern times in order to point up the complexity and profundity of philosophy's relations with the comic.

\section{The Ridiculous Philosopher}

The first tradition can be traced back to the very birth of philosophy, to Thales of Miletus $\left(6^{\text {th }}\right.$ century B.C.), who is ridiculed for falling into a well while looking at the sky (Aesop 1954: chap. 65, 75). Plato adds a mocking Thracian servant to Aesop's story about the absentminded astronomer, clearly inferring a direct line from the fall of Thales to the ridicule and death of Socrates (Plato Theaetetus, 174b-e). From antiquity to the present, this anecdote has been recorded by many with notable variations: Diogenes Laertius, Tatien (recorded by 
Stobaeus), Cicero, Ovidius, Philo, Isebius, Augustine, Tertullian, Pierre Damien, Michel de Montaigne, Francis Bacon, Pierre Bayle, Jean de La Fontaine, Voltaire, Immanuel Kant (on Tycho Brahe), Ludwig Feuerbach, Eduard Gans, and Martin Heidegger. This tradition views philosophy first as laughable to society, and later, as laughable both to theologians and philosophers who prioritize practice over theory.

The tradition of ridiculing academic philosophers begins with Heraclitus laughing at his predecessors, followed by Diogenes, the Cynic, scorning Plato. The Hellenistic philosophers Epicurus and Timon, the Skeptic, ridicule other philosophers, and Lucian mocks them all for their abstractions. In the Middle Ages, theologians follow in the footsteps of these critical philosophers by ridiculing philosophy's emphasis on reason as a way to prioritize faith in God as a condition for salvation. In the controversy over the nature of Philosophy, Renaissance philosophers such as Erasmus and Montaigne ridicule the philosophers and theologians of the Middle Ages who become entangled in abstractions instead of prioritizing life as the true philosophic and theological concern. In modern times, the third earl of Shaftesbury ridicules theorical thought and academic philosophy. He is followed by Friedrich Nietzsche and Georges Santayana and, more recently, by Gilles Deleuze. Following Erasmus and Feurebach, Søren Kierkegaard ridicules Georg W. F. Hegel's abstractions and Hegelian theologians who are forgetful of the individual's genuine life of faith (Blumenberg 2000). It is not surprising, then, that the Stoic Epictetus makes the capacity to withstand ridicule one of the strengths needed by the philosopher, and the neo-Stoic Shaftesbury makes ridicule the test of truth (Epictetus 1926, The Manual, chap. 22; Shaftesbury 1963: I, 44; 52).

\section{The Laughing Philosopher}

Beginning with Democritus ( $5^{\text {th }}$ century B.C.), this tradition features philosophers whose final judgment of life is expressed in laughter. The tradition derives its importance from Democritus' nickname while alive, 'wisdom', because it points to a fundamental association between wisdom and laughter. It is in the testimonia rather than in the fragments of his extant writings that a justification for the name can be found.

According to the legend, Democritus laughs so much that the people of Abdera believe he has gone insane and call Hippocrates to heal him. But when Democritus explains to the doctor that he is laughing at the folly of humankind, Hippocrates concludes that Democritus is truly wise and earnest, and that he is laughing to make a serious point. Democritus has been referred to as 'the laughing philosopher' ever since, and has had an immense influence on Western philosophy and literature [2].

Democritus is not alone: Seneca, Montaigne, Erasmus, Thomas More, Nietzsche, and Santayana are all recognized as laughing philosophers. Satirists such as Horace and Juvenal refer approvingly to Democritus' characteristic attitude toward the faults of mankind. However, since Democritus' admonition, 'you people do not laugh at your own stupidity but each laughs at another's (Hippocrates 1990: Letter 17, line 5), it is expected that laughing philosophers laugh first of all at themselves (Seneca 1995: On Firmness, 16.3-17.4; Montaigne 1965, bk. I, chap. 50: 503; Nietzsche 1954, Part IV, chap. 12, sec. 18 and 20; Santayana 1948: 44-45).

Democritus is soon paired with Heraclitus, who is often associated with the combination of melancholy with arrogance and who is known as the 'weeping philosopher' by the Roman period (Chitwood 2004: chap. 2). Following Sotion, who first opposes Democritus and Heraclitus, and his student Seneca, who first compares the opposing worldviews represented by these two philosophers, there are many who choose one over the other, including Juvenal, 
Lucian of Samasota, M. A. Fregoso, Etienne Forcadel, Montaigne, Baruch Spinoza, Voltaire, Lope de Vega, Walter Scott, Victor Hugo, and Santayana.

Because Hippocrates first thought that Democritus was a victim of the black bile, on which he was writing a book, Democritus also begins the tradition of laughter and melancholy, which is considered in the Middle Ages the medical form of acedia or the sin of being disgusted by God. Humanist authors attribute this melancholic laughter to Democritus, preferring him to the weeping Heraclitus. The idea, already found in Aristotle, that melancholy is associated with genius takes root in the Renaissance. Laughing philosophers are thus divided into two trends according to different interpretations of Democritus' laughter, either misanthropic and melancholic, or cheerful.

\section{The Comical Philosopher}

Epitomized in Socrates ( $5^{\text {th }}$ century B.C.), this tradition features the archetype of the teacher and the embodiment of philosophy as both a laughing and laughable philosopher. Not only is Socrates ridiculed, but there is something fundamentally comic in his appearance as well as in his conversations. As the main character of Aristophanes' Clouds, he enters literature through the door of comedy, and his comical image is perpetuated in the Socratic dialogues (as humorous in Xenophon and ironic in Plato) and endures throughout antiquity. Socrates embodies a comic couple, and the comic role he takes on as part of the dynamism of the couple that he appropriates together with his comical degradation are necessary conditions for the exercise of his thought and especially for its development in others (Beltrametti 2000: 223-226).

The paradoxical duality that he uses as a method for teaching philosophy is expressed in an inextricable connection between the serious and the ridiculous or between the sublime and the low, because the comical challenges serious norms. Socrates calls into question, both in thought and in deed, the appropriateness of the categories conceived and considers the comic as conducive to truth telling, as is shown in Alcibiades' speech in Plato's Symposium: by taking none of the normal things seriously while devoting himself with great earnestness to arguments about cobblers and carpenters, Socrates, the silenus, problematises the serious. Such eccentricities (atopia) combined with his ironic manner and satiric appearance make Socrates a genuinely serio-comic figure.

In the Renaissance, Alcibiades' depiction of Socrates as a paradoxal silenus is reprised by Erasmus in the characterization of Socrates as a wise fool, and, following Jerome's and Augustine's earlier comparison between Socrates and Christ, Erasmus transforms Socrates into a forerunner of Christ (Adages, 1965-72: 271). This image is pitted against one which many Enlightenment writers favour, that of Socrates as a supreme rationalist. In the $18^{\text {th }}$ century, two Socratics who make use of the comical Socrates stand out, the third Earl of Shaftesbury and Johann Georg Hamann. Shaftesbury uses Socrates not only for the picture of the moral philosopher, but also for the dialogic and ironic authorial manners of the texts written by Plato and Xenophon. Shaftesbury maintains that the aim of the philosopher is to edify by furthering the other's autonomy. Endorsing the Socratic skeptical methodology in his collected writings, Shaftesbury urges his readers to embark on an open-ended quest for truth, in which his extensive use of wit, humour and irony, and an occasional assumption of an external perspective ostensibly not his own, serves to dismantle the writer's authority (Shaftesbury 1963). For Hamann, God works in ironic ways to advance his purpose, and faith, rather than knowledge, is the answer to ignorance. In his works, Hamann seeks to emulate the Alcibiadean shell, hiding the Christian message the same way Socrates has hidden Pagan 
ethics. Hamann sees himself as the Socrates of Christianity, with his wooden arm showing the way, the role that Kierkegaard later adopts for himself along with Hamann's literary method, which requires direct personal involvement and indirect communication (Hamann 1967).

During the $19^{\text {th }}$ century an ironic Socrates steadily replaces a comic Socrates and has the exclusivity today. Although irony has been identified with Socrates since Aristotle, it was criticized by many before Socrates and after Aristotle. Not only did the Peripatetics reject irony (Aristotle 2000: 4. 7. 1-17; Theophrastus 2004: I, 1-6), so do the Platonists since the $1^{\text {st }}$ or $2^{\text {nd }}$ century A.D. following their acceptance of the Aristotelian view of irony as a vice (Sedley 2002: 45). The Epicurean school disliked Socrates, and rejected irony much as it shunned rhetoric, perceiving in both a kind of artifice incompatible with the pursuit of truth (Cicero 1962: 292; Quintilian 2001: 2.17. 15; Plutarch 1967-1984, Against Colotes 1127A). The Stoics venerated Socrates yet did not find irony worthy of study and rejected it altogether as foul: 'For no one manly [eleuthros] and grave [spoudaios] engages in irony' (Stobaeus, in Arnim 1903-1905: III, 161. 4). Too harsh to take a kindly view of the refined weapon of irony, the Cynics favoured 'sardonic laughter' (Dudley 1967: ix). Until the Renaissance, irony was not associated with the comic (Knox 1989: 98-99). Moreover, only since Romanticism's interest in irony has Socrates' irony come to the fore and Plato's account been favoured (Nehamas 1999: 94). How Socrates' comicality should be characterized and his irony understood are still controversial issues debated among contemporary prominent scholars, such as Alexander Nehamas and Gregory Vlastos (Nehamas 1999; Vlastos 1991).

\section{Philosophy is Comedic}

For some followers of Socrates, such as Plato and the Cynics $\left(5^{\text {th }}\right.$ century B.C.), the comic fulfils such a pervasive role that their practice of philosophy is aptly equated with comedy. Its laughter in various forms (irony, wit, sarcasm, humour) is an important means for conveying philosophical ideas that appear paradoxical because they are at odds with established social values; the quick cognitive shifts and reduced anxiety levels produced by laughter attract attention, overcome resistance, and prompt change, enabling listeners or readers to contemplate both sets of values-society's and philosophy's-simultaneously.

In Plato's Laws, the justification of the use of the comic is intellectual: the serious cannot be taught without the ridiculous (Laws, VII, $816 \mathrm{~d}$-e). In the Philebus, however, the proper aim of comedy is to unmask ignorance and pretension, making it thus an important tool for furthering the moral aim of self-knowledge (Philebus, 48A-50B). Given this emphasis, Plato's Socratic dialogues-the conversation, character, and irony of Socrates combined with the laughable element Plato introduces in the format of parody and myth-can be seen as philosophical comedies: some of his works are tragic-comic (Symposium, Republic), while others are infused with a spirit of comedy so pervasive that they become burlesque (Cratylus, Euthydemus). All of Plato's works reflect actual comic drama and use comic techniques (Brock 1990: 39-49).

The Cynics justify the comic on moral grounds by integrating into philosophy the promising alliance between humour and moral teaching used by Aristophanes and other comic poets and playwrights. Their philosophy begins as physical comedy: tradition is unanimous on the remarkable powers of ridicule and repartee of the Cynic Diogenes and the notorious eccentricities undertaken to expose the artificiality of convention - entering a theatre when everyone else is leaving it, going about in broad daylight with a lighted lantern, looking for an honest man. The philosophic wit introduced by Diogenes is further developed by Crates, who, purporting to cure human confusion with gentle discourse accompanied by 
much joking, laughter, and merriment and the example of his life, 'passed his whole life jesting and laughing, as though on perpetual holiday' (Plutarch 1948: 4.226E). Cynical comedy is literary as well: for the purpose of furthering philosophic education, the Cynics invent a literary genre, the serio-comic (spoudaiogeloion), which is primarily an attempt to adapt the 'Socratic' forms of popular philosophical propaganda to the requirements of the Hellenistic age (Giangrande 1972).

The Romans give the serio-comic its own genre in the form of satire, notably in the poets Horace and Juvenal, the former explicitly arguing in Ars poetica that the best ethical instruction (the utile) is mixed with pleasure (the dulce) (Horace 1989: 343.3). Although late antiquity and the Middle Ages are fond of the antithesis between jest and earnestness, they nevertheless lose their ability to conceive of the two in synthesis. Erasmus, an important figure in the serio-comic tradition, retrieves Lucian's capacity for using humour to provoke the audience into considering a subject simultaneously from divergent points of view (Erasmus 1971). Because his books are translated and read all over Europe, he is considered largely responsible for the ironic smile curling so many $16^{\text {th }}$ century lips (Gordon 1990). Pascal says that eloquence 'requires the pleasant and the real', but the pleasant must 'itself be drawn from the true'; Christian laughter is thus a saintly ridicule of human mistakes, and derisive laughter should be praised for awaking us to the earnestness of existence (Pensées 1941: Fragment 562; The Provincial Letters, 1941: Letter 11).

With the Cynics' influence on all Hellenistic schools (Long 1996) and the influence of these schools on the Renaissance and the Enlightenment, the serio-comic becomes the main form of exoteric writing in philosophy. It is used, among others, by the Stoics, Lucian, Erasmus, Montaigne, Shaftesbury, Nietzsche, Kierkegaard, and Santayana.

\section{Wit is a Virtue}

Beginning with Aristotle ( $4^{\text {th }}$ century B.C.), this tradition maintains that laughter used correctly is a virtue, thereby making laughter a part of the good life. Eutrapelia, the "true wittiness" characteristic of an honourable and free person, is an Aristotelian social virtue, which is midway between the excess of laughter (buffoonery) and its deficiency (boorishness) (Aristotle 2000: 4.8. 1127b).

We have evidence from Diogenes Laertius that Theophrastus wrote a treatise on laughter, which has unfortunately not been preserved. The loss is considerable, for it would have provided the necessary connection between Aristotle and later Roman writers on laughter. Theophrastus' own ideas were carried forward, at least, by two writers on laughter: the first, Demetrius Phaedrus (first century A.D.), in some sketchy fragments; and the second, Plutarch, who quotes from Theophrastus in discussing the suitable jest, in his Quaestiones conviviales. Plutarch defines quite closely the requirements of the liberal jest: it must give pleasure and not pain; it must observe the proprieties of time and place; it must not be forced, or frigid, but spring naturally from the conversation. One should ridicule innocent 'hobbies' rather than serious faults, and slight physical defects rather than grave ones. The jester should show his good will by laughing sometimes at his own expense, and should never show a bitter spirit in his jesting (Frazier 2000).

Theophrastus, Demetrius, and Plutarch are important channels in the transmission of the Aristotelian theory of humour. The Stoic philosophers, represented by Diogenes of Babylon and Panaetius of Rhodes (c. 185-109 B.C.), constitute a different channel of transmission. Their theory of plain style and its appropriate humour directly influence the members of the Scipionic circle at Rome, who extend their influence to Cicero. The Stoic Panaetius' views 
are preserved in the adaptation of his work On the appropriate by Cicero in the latter's De Officiis (2001a). Panaetius incorporates Aristotle's views into Stoicism to make the school palatable to the Romans. He takes virtue to be a mean between two vices; alien to true Stoic principles, this doctrine forms the basis of Cicero's attitude towards laughter in De Officiis. Moreover, Socrates becomes for Panaetius the ideal embodiment of Aristotle's eutrapolos or Cicero's liberal joker (the latter's coining for Aristotle's free man). Assailling the aesthetic and moral coarseness of Cynic speech with its frank humour as a sin against social propriety, Panaetius finds the jest most appropriate for the plain style his teacher Diogenes of Babylon advocates (Fiske 1920: 17).

The Stoic-Peripatetic tradition of the liberal jest preserved in Cicero's De Officiis and De Oratore has a great historic influence (Cicero 2001a; 2001b). Yet Aristotle's eutrapelia gains eventually a negative connotation in Greek and Roman culture (Verdon 2001: 17) which reaches its peak with Christianity. In his Epistle to the Ephesians, St. Paul counts eutrapelia among the vices to be avoided: 'neither filthiness, nor foolish talk, nor jesting, which is not convenient' (Epistle to the Ephesians, 5: 4). Thomas Aquinas revives the Aristotelian social virtue of wit as appropriate laughter for the free person (Aquinas 1972: IIII, quest. 168, art. 2).

The Renaissance follows scholastic and Thomistic thought. To make an audience laugh by telling faecetia is the mark of Renaissance urbanity (Ménager 1995: chap. 5). He does not endorse St Paul's condemnation of eutrapelia: Entirely different from buffoonery (scurrilitas), eutrapelia is synonymous of faecetia or lepos. He creates a literary character named Eutrapelus, which literally means 'happy turn' or 'to be witty', who is accompanied by 'Gelasinus' (the laugher) and 'Philogelos' (the friend of laughter) [3].

From the middle of $16^{\text {th }}$ century to the $18^{\text {th }}$ century, a political-religious attack of seriousness starts in reaction to the Renaissance. Laughter is relegated to the opposition. Reduced to its critical, mocking and derisive function, it becomes bitter or resentful. Most Christian thinkers condemn it and most philosophers mistrust it. Yet Spinoza affirms that when we laugh rather than mock we experience the 'pure joy' that enables us to partake in God's nature; perhaps influenced by Spinoza (Robertson 1963: xxxi), the third Earl of Shaftesbury makes humour the supreme virtue, a view that influences his numerous followers who help to craft the notion of benign humour. $19^{\text {th }}$ German philosophers and English authors turn humour into a religion of the mind [4]. In addition to Shaftesbury, Hamann, Kierkegaard, Nietzsche, Santayana, Georges Bataille, Gilles Deleuze and Clément Rosset consider humour or laughter essential to the good life. Finally, various contemporary philosophers consider humour a virtue (i.e., Roberts 1988; Lippitt 2005; Amir 2002; Comte-Sponville 1995).

\section{Laughter is the Mark of Humanity}

Originating in an extrapolation of Aristotle's phrase 'man is the sole animal that laughs'-an empirical observation on the human physiological reaction to tickling-this tradition sees laughter as the mark of the human (Aristotle 2001: III, 10, 673a, 8, 28). Another mark of the human is logos, the capacity to speak or to think rationally (Aristotle 1988: 1253a; 2000: 1178a5). During the same time, belief in a laughing animal (animal ridens) is also supported by Julius Pollux (Onomasticon) and by the prominent Roman physician and philosopher of Greek origin, Galen of Pergamum, whose theories dominated Western medical science for well over a millennium.

Aristotle does not associate laughter with speech or rational thought and does not mention laughter in his discussion of the properties of the human being in his Categories and 
Topics. Subsequent philosophers do, however, and thereby influence later generations. After Quintilian, who associates laughter with speech (2001: V, 10, 58), and Lucian, the philosopher-satirist from the $2^{\text {nd }}$ century A.D., who associates laughter with the human capacity to calculate (1913-1967: Sale of Creeds, 26; Demonax, 21), Porphyry of Tyre considers laughter a feature that is invariably possessed by humans, by all humans, and by humans alone. In his $3^{\text {rd }}$ century A.D. introduction (Isagoge) to Aristotle's Categories, he mistakenly attributes this view to the latter (Porphyry 1975: IV, 4, 14). Because Porphyry's book is used as the standard text-book of Aristotelian logic in the Middle Ages, his mistake resonates for at least a thousand years after his death. But Porphyry maintains the Aristotelian differentiation between property and essence and between potentiality and actuality: only lunatics or enlightened beings laugh all the time. Thus, in allocating a humble place to laughter, Prophyry remains faithful to Aristotle

In the $5^{\text {th }}$ century, Marcianus Capella also supports the idea that the human being is the only animal that laughs (Capella 2007). However, it is Boethius, in his commentary on Prophyry's book at the beginning of the next century, who emphasizes laughter as the privilege of the rational human being and who characterizes the capacity to laugh as a proprium of humanity. The $7^{\text {th }}$ century philosopher, Alcuin, proposes a more elaborated yet essentially similar formula: "Homo est substancia animate, rationalis, mortalis, risus capax" (Minois 2000: 125). After the $11^{\text {th }}$ century, it is Boethius' view that is transmitted as the Aristotelian view by the Benedictine monk, Notker Labeo. Laughter attains to a rank similar to that of reason as the proprium that differentiates the human being from the animals-a view that benefits from the respectability associated with Aristotle's philosophy.

Known as homo ridens, this tradition reaches its apogee in the Middle Ages, when scholars identify rationality with the capacity to laugh (Dante 1965: 54; Verdon 2001), and in the Renaissance, when laughter is considered fit for a world that is not a valley of tears and for a being made of contradictions (Ménager 1995). This tradition emphasizes philosophy's special interest in laughter inasmuch as laughter reveals the essence of the human by its affinity with the rational, or otherwise. Following Julius Pollox, Galen, Porphyry, Marcius Capella, Boethius, Alcuin, and Notker Labeo, Laurent Joubert, Montaigne, François Rabelais, Charles Baudelaire, Voltaire, and Jean-Paul Sartre, among others, belong to this tradition. Although we know today that humans are not the only animals that laugh (Panksepp 2007), contemporary philosophers revive this view, with humour replacing laughter - a change due to the zeitgeist. The question of the relation between rationality and certain forms of laughter, such as humour, is still actual today (Morreall 1983: 100; Gelven 2002: 1; Heller 2005: 29).

The tradition that considers the human being the only animal that laughs (homo ridens) should be complemented by the view of the human being as the laughable animal (homo risibilis). Many hold the former view but few hold also the latter. Though this characteristic of the human does not escape Plato's keen eye in his discussion of laughter in the Philebus (48-50), Plato does not apply it to all persons, but only to those who are lacking in both selfknowledge and power. It is Notker Labeo who innovates with his claim that the human being is not only the sole creature capable of laughter, but also the sole laughable creature: we laugh only at that who is human or that who reminds us of the human (quia quidquid risibile est, homo est) (Labeo 1972-1996). Montaigne revives this view by maintaining that we are both homo ridens and homo risibilis as "our own specific property is to be equally laughable and able to laugh" (Montaigne 1965: bk. I, chap. 50). Bergson draws attention to this defining characteristic at the very beginning of his book on laughter: 'Several have defined man as "an animal that laughs". They might equally have defined him as an animal that is laughed at' (Bergson 1999: 9). Recently, Simon Critchley has reprised both characterizations (Critchley 2002: 41). 


\section{The Laughless (agelastos) Philosopher}

Beginning with Pythagoras, the first to call himself a philosopher $\left(6^{\text {th }}-5^{\text {th }}\right.$ century B.C. $)$, this tradition features the philosopher as never laughing because he is too preoccupied with lofty ideas to be engaged in such an earthly matter (Laertius 1925: 8.20). Identified also with the pre-Socratic philosopher, Anaxagoras, this character made frequent appearances on the Greek comic scene.

The ideal of the perfect human being who never laughs (the agelastos) is shared by Greek philosophers, Egyptian priests, Jewish ascetics, and Christians: Jerome, Basil, and John Chrysostom opposed laughter and jocularity, as did the Church Fathers in general (Adkin 1985: 149-152). This was justified by the view that there is no account of Jesus laughing in the Gospels. Laughter is mentioned in the reported sayings of Jesus, but it is to berate those who laugh in godless sinfulness and to announce that they will weep in the fullness of time, while those who weep now are blessed and will laugh later (Luke 6:25;21). At the same time Aristotle's thesis that laughter is a distinctive characteristic of the human being-the idea of homo ridens, "man gifted with laughter"-appears in both the Latin and the medieval Christian Latin traditions. A heated debate on laughter with far-reaching consequences arises in the Middle Ages. If Jesus, the great model of imitation for humanity, never laughs during his human life, then laughter must be alien to man, at least to Christian man. Conversely, if one posits that laughter is a distinctive feature of humankind, then homo ridens will certainly feel more able to express his own nature. Both views are found in ecclesiastical authors (Le Goff 1992: 72-74).

As mentioned above, Aristotle's eutrapelia gains a negative connotation in Greek and Roman culture, which eventually reaches its peak with Christianity. Wit is condemned by Ignatius, Clement of Alexandria, and Origen, as well as by Basil and John Chrysostom in literally dozens of passages. Monastic rules proscribe laughter; conversely, weeping over the wretchedness of this world is praised as a Christian virtue. Christian saints rarely laugh except in defiance of imminent martyrdom.

Around the $12^{\text {th }}$ century, the Church brings laughter under control by distinguishing good laughter from bad laughter, i.e. admissible ways of laughing from inadmissible. The Church reaches a codification of the practice of laughter, of which scholasticism assumes ownership. The Church's relation with laughter has not evolved much since Thomas Aquinas' rehabilitation of the Aristotelian virtue of wit or eutrapelia, a plea for restrained laughter followed by Pascal (Aquinas 1972: II-II, quest. 168, art. 2; Pascal, The Provincial Letters, 1941: Letter 11). Before the middle of the $20^{\text {th }}$ century, only the Gnostics recognize Christ's laughter [5]. Christian behaviour, however, is more varied than Christian theoretical considerations (see Bakhtin 1968).

In modern times, the Puritans inherent the ideal of the agelostos, and traces of the laughless ideal gentleman persist in the famous letter Lord Chesterfield writes to his son (Chesterfield 1901: Letter 144, 9 march 1748). Today, although a sense of humour is appreciated, everybody knows that serious persons do not laugh, because seriousness and laughter are incompatible.

\section{The Mocking Sophist}

Beginning with the Sophist Gorgias Leontinus ( $5^{\text {th }}$ century B.C.) and recorded approvingly by Aristotle, this tradition recommends laughter as a rhetorical device to destroy the opponent's argument, which has led to a whole branch of Greco-Roman rhetoric. Aristotle records that 
'Gorgias said it was necessary to spoil the seriousness of opponents by jest and their jest by seriousness' (Aristotle 1970: 3.18.7). Aristotle begins a serious study of "wit" that reappears in treatises on stylistics and discourse through the 20th century as linked principally to concerns of ethos (the nature and character of the rhetor as portrayed in the speech) and pathos (an appeal made to alter the judgement of an audience). The rhetor's treatment of wit is further involved in the practice of 'dissimulating', 'understating', or 'hiding' his underlying intensions, called eironeia. Aristotle uses the word to describe a kind of intelligent 'mock modesty', which is deviant from the truth but which is preferable to a boisterous character.

Aside from Aristotle's references to understatement and mockery, antiquity left us with two prominent treatments of humour in oratory situations - Marcus Tullius Cicero's dialogical de Oratore (c. 46 B.C.) and Quintillian's Institutio Oratoria (c. 95 A.D.). Although rhetoricians in the Middle Ages and the Renaissance are advised to cut on their wit lest their character be damaged (Graban 2008: 405), through Cicero's and Quintilian's influence on later generations, wit becomes a weapon in modern rhetoric (Sanders 1995: chap. 4).

Since Plato's Socrates, most philosophers denigrate rhetorical wit (Plato, Gorgias 473e); John Locke's and Immanuel Kant's objections to wit are representative of philosophers' willingness of differentiating themselves from rhetoricians (Locke 1984: vol. 2, bk. 3, chap. 10, sec. 34; Kant 1952: sec. 53). The latter circumvent reason by addressing the emotions, whilst philosophers address reason. This tradition, when combined with the tradition of the mocking sophist and disconnected from all other traditions, explains how the view that philosophy is inimical to the comic took hold. However, two other traditions that originate in the $18^{\text {th }}$ and $19^{\text {th }}$ centuries shed light on the contemporary interest of philosophers in the comic.

\section{Laughter is Epistemologically Valuable}

Originating with the British Philosopher of the Enlightenment, the third Earl of Shaftesbury, this tradition recognizes an epistemological value in laughter, as laughter helps us grasp the truth. Shaftesbury's originality lies in his unprecedented and unparalleled defence of humour, wit, ridicule, and good humour as important epistemological tools that promote truth and rationality. Shaftesbury considers ridicule a test of truth, humour a tool for reason, properly educated laughter a form of critical reflection, and good humour or cheerfulness the disposition in which philosophical and religious truth are most effectively comprehended. For Shaftesbury the deist, truth is the benevolence of God, the harmony of nature, and innate human goodness (Shaftesbury 1963).

The view that ridicule is a test of truth gains followers in the $18^{\text {th }}$ century after having been at the heart of a raging controversy over ridicule's relation to truth and reason (Aldridge 1945: 129-156). The idea that humour has a habilitating function with regard to truth influences Johan Georg Hamann, Shaftesbury's translator and follower, and through Hamann, the young Søren Kierkegaard. For Hamann, truth is the 'Word that has become flesh', and humour and irony are the only appropriate modes of thought for grasping this paradox. Humour affirms that God is wholly other and that Divine reason is fundamentally disjunctive with human reason and consequently bound to appear absurd to humans. Humour is the appropriate human attitude toward Divine folly because only in the absurd does the possibility of seeing God arise. Humour's positive function is to open a person to the acceptance of the reality of paradoxical truth and ultimately to the acceptance of the highest paradox of all-the incarnation. Thus, for Hamann, humour is the road to salvation (Alexander 1966: chaps. 7-8). Following Hamann, the young Kierkegaard holds the view that the comic enables us to grasp 
the truth of Christianity, as Christianity is the most humorous of all religions (Kierkegaard 1967-1978: I, 206; 208-210; 216-217). Eventually disengaging himself from Hamann, Kierkegaard rejects this view, arguing that Christianity is inaccessible to humour. $\mathrm{He}$ nevertheless retains the idea that the comic is epistemologically valuable. The comic is the only criterion of inner advancement available on the negative Kierkegaardian theological ladder towards God. It is the only positive indicator of the individual's relation to the truth, because the form of the comic the individual enjoys reflects his position in the hierarchy of the existential stages of life that Kierkegaard devises [6].

\section{Laughter is Ontologically Rooted}

George Santayana in the English speaking world $\left(19^{\text {th }}-20^{\text {th }}\right.$ century) and Clément Rosset in the French speaking world ( $20^{\text {th }}$ century) are at the forefront of a tradition that views laughter as ontologically rooted because reality itself is comical (Santayana 1922: 142; Rosset 1991: 54; 59). Antedating these philosophers, Georg W. F. Hegel followed by Kierkegaard discloses an ontological basis for the comic in yet another sense. Hegel asserts that the discrepancy between an assumption and reality that produces laughter is grounded in reality itself. The comic, for Hegel, always has an ontological dimension because it tells us something about the being of its object and, in a sense, about being itself. This follows from his conception of dialectics, according to which the truth is never fixed, but is rather articulated and realized in contradictory ways. The comic is precisely an awareness of this contradiction (Hegel 1970: 527-530).

Kierkegaard, too, ties the comic to contradictions or incongruities that are objective because constitutive of the human self. They are the finite and the infinite, singularity and generality, reality and ideality-in short, the human being's bodily time-limited existence and his aspirations toward the eternal. While the discrepancy between reality and ideality that calls for a tragic or comic interpretation is objective because it refers to a general human predisposition or ideality, to a framework of existence that is pre-given in an objective way, the comic or the tragic are points of view generated by considering the discrepancy from ideality to reality and from reality to ideality, respectively. Due to the reflexive aspect of the comic, however, the comic contradiction is 'objective', in the sense that it is discernible to the detached, 'selfless' eye. The comic has an objective basis in reality insofar as there is an objective truth (cf. Christianity) that determines the hierarchy of forms of life according to their distance from Christianity. It is comical whoever misrepresents this hierarchy and feels superior while being actually inferior. That which counts as legitimately comic is grounded in reality as a feature of the world, whether or not any particular person can appreciate it (Kierkegaard 1992: 513; 630; 622).

\section{Conclusion}

This article addresses the question of the relations between philosophy and the comic. The accepted view that maintains that there is no relation between them rests on two ancient laughter traditions, namely, the laughless philosopher (Pythagoras) and the mocking sophist (Gorgias), which, isolated from the rest of the traditions, were taken conjointly to represent philosophy's relation with the comic. These traditions do not exhaust the relationship of philosophy and the comic. Eight additional traditions, as shown above, testify to a positive relation between philosophy and the comic yet vary on the nature of this relation. 
Philosophy's inception and history is rich with theories and practices of the comic. Many philosophers considered laughter the mark of the human and several have considered some form of it a virtue. Since the $18^{\text {th }}$ century, moreover, philosophers' interest in laughter is intensified because of its epistemological powers and ontological roots. Furthermore, laughing philosophers have existed all along history. Finally, the traditions of the Ridiculous Philosopher, the Comical Philosopher and Philosophy as Comedic, when considered together reveal that philosophy entertains an essential relationship with the comic: Philosophy is a subversive teaching that runs counter to society's common truths and accepted values; laughter represents those truths and values in a nutshell because it presupposes an attack on all that endangers them. Philosophy necessarily re-educates our laughter by provoking it in order to redirect it towards worthier objects. Using his whole being as a pedagogical tool, the Ridiculous Philosopher turns into a Comical Philosopher who initiates a laughing relationship with others, in order to challenge and hopefully change their values. The span and the scale of the comic that is used by the philosopher determine whether the relationship with the others becomes a Philosophic Comedy.

Philosophy begins by criticizing laughter and ends by indicating a new way of laughing. This is so because the revolution of values it operates requires a new taxonomy of the serious and the ridiculous, of the important and the negligible, of that which is worthy and unworthy of laughter. It is not sufficient to laugh in order to live well, it is equally important to laugh well: a good life, philosophy maintains, means having a good laugh [7].

\section{Notes}

[1] I have not found a record of these traditions in the secondary literature. At most, studies on literary satire refer to two irreconcilable camps, namely, the Peripatetic tradition followed by Cicero, and the Iambos tradition seen in Iambic poetry, Old Comedy, Cynic moralizing, and Lucilius. For the conventional division between these camps, see Freudenburg (1993). For valuable information on Greek laughter, yet mostly unrelated to the division into the traditions I propose, see Halliwell (2008).

[2] The laughing Democritus is found in a Greek anonymous legend of the first century B.C., the Novel of Hippocrates, composed of a collection of 27 apocryphal letters of the renowned $5^{\text {th }}$ century B.C. doctor. See Hippocrates (1990: Letters 10-17). In the Latin testimony, at the latest in Horace's days ( $1^{\text {st }}$ century B.C.), Democritus was referred to as 'the laughing philosopher'. For the laughing philosopher's legend, see Salem 1996. For his influence throughout the centuries, see Muller (1994: 39-51).

[3] Erasmus, 'Commentary on the Epistle to Ephesians', Novum testamentum, Opera Omnia, 20062009, vol. VI, col. 850, n. 4. Eutrapelus is found in Erasmus' colloquium 'Puerpera' (1965-1992); as a literary character it is also found in Noël du Fail's Les Balivernies d'Eutrapel (1548) and les Contes d' Eutrapel (1585).

[4] See Spinoza (1985: IV, Prop. 45 Corrolary 2, and Scholium); Shaftesbury (1963). For the interest in benign humour in the $18^{\text {th }}$ century, see Tave (1960). For Thomas Carlyle, Jean Paul, and Moritz Lazarus, see Amir (2014).

[5] Jesus is laughing in the writings of ancient Coptic Gnostics. See the Apocalypse of Peter 81:11 and 83:1, translated in Robinson (1990: 377); and the Gospel of Judas 2.3-7; 3.6; 9.3; 14.12-14, translated in Pagels and King (2007: 109-110; 111; 115; 120).

[6] For Kierkegaard's view of the comic, see Amir (2013). For Shaftesbury, Hamann, and Kierkegaard and their different approaches to truth's relation to the comic, irony, and humour, see Amir (2014).

[7] A partial version of this article has been presented in conferences: the key-note lecture 'The Comic in the History of Philosophy' delivered at the International Society for Humor Studies $20^{\text {th }}$ Conference in Alcalà de Henares, Spain, 2008; and the lecture 'Philosophy and the Comic' delivered at the Israeli Society for Humor Studies Conference at Ashkelon College, Israel, 2010. An incomplete version of 
this article has been published in a volume of essays, in Hebrew, following the latter congress (Amir 2012).

\section{References}

Adkin, N. (1985). 'The Fathers on Laughter', Orpheus, 6, pp. 149-152.

Aesop. (1954). Fables, trans. by S. A. Handford, with illustrations by Brian Robb. Harmondsworth: Penguin Books.

Aldridge, A. O. (1945). 'Shaftesbury and the Test of Truth', Publications of the Modern Language Association, 60, pp. 129-156.

Alexander, W. M. (1966). Johann Georg Hamann: Philosophy and Faith. The Hague: Martinus Nijhoff.

Amir, L. B. (2014). Humor and the Good Life in Modern Philosophy: Shaftesbury, Hamann, Kierkegaard. Albany, NY: SUNY Press.

Amir, L. B. (2013). 'Kierkegaard and the Traditions of the Comic', Kierkegaard Studies Yearbook.

Amir, L. B. (2012). 'The Good Life Is the Good Laugh: The Comic in the History of Philosophy', in Ziv, Avner \& Sover, Arie, (eds.), The Importance of Not Being Earnest, Jerusalem: Carmel Press, pp. 206-253 [in Hebrew].

Amir, L. B. (2010). Philosophy and the Comic. Paper presented at the the Israeli Society for Humor Studies Conference, Ashkelon College, Israel (in Hebrew).

Amir, L. B. (2008). The Comic in the History of Philosophy. Key-note Lecture delivered at the International Society for Humor Studies $20^{\text {th }}$ Conference, Alcalà de Henares, Spain.

Amir, L. B. (2002). 'Pride, Humiliation and Humility: Humor as a Virtue', International Journal of Philosophical Practice, 1(3), pp. 1-22.

Aquinas, T. (1972). Summa Theologiae, trans. by Thomas Gilby. London: Backfriars.

Aristotle. (1970). The Rhetoric of Aristotle, Sandys, John Edwin, (ed.). Hildesheim: G. Olms.

Aristotle. (1988). The Politics, Everson, Stephen, (ed.). Cambridge: Cambridge University Press.

Aristotle. (2000). Nicomachean Ethics, trans. and ed. by Roger Crisp. Cambridge: Cambridge University Press .

Aristotle. (2001). On the Parts of Animals I-IV, trans. with an introduction and commentary by James G. Lennox. Oxford and New York: Oxford University Press.

Arnim, H. von. (1903-1905). Stoicorum veterum fragmenta, 4 vols. Leipzig.

Bakhtin, M. (1968). Rabelais and his World, trans. by Helene Iswolsky. Cambridge, MA: MIT Press.

Beltrametti, A. (2000). 'Le couple comique: Des origins mytiques aux dérives philosophiques', in Desclos, Marie-Laurence, (ed.), Le Rire des Grecs: Anthropologie du rire en Grèce ancienne, Grenoble: Jérome Millon, pp. 215-226.

Bergson, H. (1999). Laughter: An Essay on the Meaning of the Comic. Trans. C. Bereton and F. Rothwell. Kobenhavn and Los Angeles: Green Interger.

Blumenberg, H. (2000). Le Rire de la servante de Thrace: Une histoire des origines de la théorie, trans. by Laurent Cassagnau. Paris: L'Arche.

Brock, R. (1990). 'Plato and Comedy', in Craik, E. M., (ed.), "Owls to Athens": Essays on Classical Subjects Presented to Sir Kenneth Dover, Oxford: Clarendon Press, pp. 39-49.

Capella, M. (2007). Les noces de Philologie et de Mercure, Ferré, Michel, (ed.). Collection des Universités de France. Paris: Les Belles Lettres.

Chesterfield, Earl of. (1901). The Letters of the Earl of Chesterfield to his Son. London: C. Strachey.

Chitwood, A. (2004). Death by Philosophy: The Biographical Tradition in the Life and Death of the Archaic Philosophers Empedocles, Heraclitus, and Democritus. Ann Arbor, MI: The University of Michigan Press.

Cicero, M. T. (1962). Brutus, trans. by G. L. Hendrickson. Orator, trans. by H. N. Hubbell. Loeb Classicial Library. London: W. Heinemann. 
Cicero, M. T. (2001a). On Obligations (De Officiis), trans. with introd. and notes by P.G. Walsh. Oxford: Oxford University Press.

Cicero. (2001b). On the Ideal Orator (De Oratore), trans. with introduction, notes, appendices, glossary, and indexes by James M. May \& Jakob Wisse. New York, NY: Oxford University Press.

Comte-Sponville, A. (1995). 'L'humour', in Petit traité des grandes vertus, Paris: Presses Universitaires Francaises, pp. 276-290.

Critchley, S. (2002). On Humour. London and New York: Routledge.

Dante Alighieri. (1965). Oeuvres Complètes, trans. by A. Pezard. Paris: Gallimard, 'La Pléiade'.

Dudley, D. R. (1967). A History of Cynicism: From Diogenes to the $6^{\text {th }}$ Century A.D. Hildesheim: Georg Olms Verlagsbuchhandlung.

Epictetus. (1926). The Discourses as Reported by Arrian, The Manual, and Fragments, trans. by W. O. Oldfather. London: William Heinemann; New York: G. P. Putnam's Sons.

Erasmus, D. (2006-2009). Opera Omnia. Leiden: E. J. Brill.

Erasmus, D. (1971). Praise of Folly and Letter to Martin Dorp 1515, trans. by Betty Radice, intro. and notes by A. H. T. Levi. London: Penguin.

Erasmus, D. (1965-1992). 'Puerpera', 'The Adages', 'The Sileni of Alcibiades', in The Colloquies of Erasmus, trans. by Craig R. Thompson. Chicago, IL: University of Chicago Press.

Fail, N. du. (1548). Les Baliverneries d' Eutrapel. Paris.

Fail, N. du. (1585). Les Contes et Discours d'Eutrapel. Rennes: Noël Glamet de Quinpercorentin.

Fiske, G. C. (1920). Lucilius and Horace: A Study in the Classical Theory of Imitation. Madison, WI: University of Wisconsin, Studies in Language and Literature 7.

Frazier, F. (2000). 'Rires et rieurs dans l'oeuvre de Plutarque', in Desclos, Marie-Laurence, (ed.), Le Rire des Grecs: Anthropologie du rire en Grèce ancienne, Grenoble: Jérome Millon, pp. 469496.

Freudenburg, K. (1993). The Walking Muse: Horace on the Theory of Satire. Princeton, NJ: Princeton University Press.

Gelven, M. (2000). Truth and Comedic Art. Albany, NY: SUNY Press.

Giangrande, L. (1972). The Use of Spoudaiogeloion in Greek and Roman Literature. The Hague \& Paris: Mouton.

Gordon, W. M. (1990). Humanist Play and Belief: The Seriocomic Art of Desiderius Erasmus. Toronto: University of Toronto Press.

Graban, T. S. (2008). 'Beyond "Wit and Persuasion": Rhetoric, Composition, and Humor Studies', in Raskin, Victor, (ed.), The Primer of Humor Research, Berlin \& New York: Mouton de Gruyter, pp. 398-447.

Halliwell, S. (2008). Greek Laughter: A Study of Cultural Psychology from Homer to Early Christianity. New York, NY: Cambridge University Press.

Hamann, J. G. (1967). Socratic Memorabilia, trans. with commentary by James C. O'Flaherty. Baltimore, MD: Johns Hopkins Press.

Hegel, G. W. F. (1970). Vorlesunge über die Asthetik III, Moldenhauer, E. \& Michel, K. M., (eds.). Frankfurt am Main: Suhrkamp.

Heller, A. (2005). Immortal Comedy: The Comic Phenomenon in Art, Literature, and Life. Lanham, MD: Lexington Books.

Hippocrates. (1990). Pseudepigraphic Writings, trans. and ed. by Wesley D. Smith. Leiden: E. J. Brill. Horace. (1989). Epistles, Book II and Epistles to the Pisones ("Ars poetica"), Rudd, Niall, (ed.). New York, NY: Cambridge University Press.

Kant, I. (1952). The Critique of Judgement: Part 1, Critique of Aesthetic Judgment, trans. by James Creed Meredith. Oxford: Clarendon Press.

Kierkegaard, S. (1992). Concluding Unscientific Postscript, trans. and ed. by Howard V. Hong \& Edna H. Hong. Princeton, NJ: Princeton University Press.

Kierkegaard, S. (1967-1978). Journals and Papers, trans. and ed. by Howard V. Hong \& Edna H. Hong, 7 vols. Bloomington \& London: Indiana University Press.

Knox, D. (1989). Ironia: Medieval and Renaissance Ideas on Irony. Leiden: E. J. Brill. 
Labeo, N. (1972-1996). De partibus logicae, in Sert, Eduard H., \& Starck, Taylor, (eds.), Die Werke Notker des Deutchen, Neue Ausgabe. Altdeutsche Textbibliothek.

Laertius, D. (1925). Lives of Eminent Philosophers, trans. by R. D. Hicks. Cambridge, MA: Harvard University Press.

Le Goff, J. (1992). 'Jesus a-t-il ri?' L'histoire, 158, pp. 72-74.

Lippitt, J. (2005). 'Is a Sense of Humour a Virtue?', The Monist, 88(1), pp. 72-92.

Locke, J. (1984). An Essay Concerning Human Understanding, Fraser, Alexander Campbell, (ed.), 2 vols. Oxford: Clarendon Press.

Long, A. A. (1996). 'The Socratic Tradition: Diogenes, Crates, and Hellenistic Ethics', in Branham, R. Bracht \& Goulet-Cazé, M.-O., (eds.), The Cynics: The Cynic Movement in Antiquity and Its Legacy, Berkeley, CA: University of California Press, pp. 28-46.

Lucian. (1913-1967). Works, trans. by A. M. Harmon, K. Kilburn and M. D. MacLeod. London: W. Heinemann.

Ménager, D. (1995). La Renaissance et le rire. Paris: Presses Universitaires de France.

Minois, G. (2000). Histoire du rire et de la dérision. Paris: Fayard.

Montaigne, M. de. (1965). Essais, Villey, P. \& Saulnier, V., (eds.). Paris: Presses Universitaires de France.

Morreall, J. (1983). Taking Laughter Seriously. Albany, NY: State University of New York Press.

Muller, R. (1994). 'Democrit-der "Lachende Philosoph"', in Jakel, Siegfried \& Timonen, Asko, (eds.), Laughter down the Centuries, 3 vols, Turku: Turun yliopisto, vol. 1, pp. 39-51.

Nehamas, A. (1999). Virtues of Authenticity: Essays on Plato and Socrates. Princeton, NJ: Princeton University Press.

Nietzsche, F. (1954). Thus Spoke Zarathustra, in The Portable Nietzsche, trans. and ed. by Walter Kauffman. New York, NY: The Viking Press.

Pagels, E. \& K. L. King. (2007). Reading Judas: The Gospel of Judas and the Shaping of Christianity. New York, NY: Penguin.

Panksepp, J. (2007). 'Neuroevolutionary Sources of Laughter and Social Joys: Modeling Primal Human Laughter in Laboratory Rats'. Behavioural Brain Research, 182 (2), pp. 231-244.

Pascal, B. (1941). Pensées; The Provincial Letters. "Pensées", trans. by W. F. Trotter, "The Provincial Letters", trans. by Thomas M'Crie. New York, NY: Modern Library.

Plato. (1966). Works, trans. by Harold N. Fowler, introduction by W. R. M. Lamb, in 12 vols. Cambridge, MA: Harvard University Press; London: William Heinemann.

Plutarch. (1948). De Tranquilitate animi, trans. by B. Snell. Zurich: Artemis.

Plutarch. (1967-1984). Moralia, vols. 1-16, Babitt, Frank Cole, (ed.), trans. by Frank Cole Babitt, W. C. Helmbold, Phillip De Lacy, Benedict Einarson, Edwin LeRoy Minar, F. H. Sandbach, Harold North Fowler, and Harold F. Cherniss. Loeb, Cambridge, MA: Harvard University Press.

Porphyry the Phoenician. (1975). Isagoge, trans. and ed. by Edward W. Warren. Mediaeval Sources in Translation, vol. 16. Toronto: Pon-tifical Institute of Mediaeval Studies.

Quintilian. (2001). The Orator's Education, trans. and ed. by Donald A. Russell. Loeb Classical Library. Cambridge, MA: Harvard University Press.

Roberts, R. C. (1988). 'Humor and the Virtues', Inquiry: An Interdisciplinary Journal of Philosophy, 31 , pp. 127-149.

Robertson, J. M. (1963). 'Introduction', in Anthony Shaftesbury, Characteristics or Men, Manners, Opinions, Times, etc. Gloucester, MA: Peter Smith.

Robinson, J. M., ed. (1990). The Nag Hamadi Library in English, $3^{\text {rd }}$ revised edition, trans. by Members of the Coptic Gnostic Literary Project. San Francisco, CA: HarperCollins.

Rosset, C. (1991). Principes de sagesse et de folie. Paris: Minuit.

Salem, J. (1996). La légende de Démocrite. Paris: Kimé.

Sanders, B. (1995). Sudden Glory: Laughter as Subversive History. Boston, MA: Beacon Press.

Santayana, G. (1922). 'Carnival', in Soliloquies in England and Later Soliloquies. New York, NY: Charles Scribner's Sons.

Santayana, G. (1948). Dialogues in Limbo, With Three New Dialogues, enlarged edition. New York: Scribner's. 
Sedley, D. (2002). 'Socratic Irony in the Platonist Commentators', in Annas, J., \& Rowe, C., (eds.), New Perspectives on Plato, Modern and Ancient, Cambridge, MA: Harvard University Press, pp. 37-58.

Seneca, L. A. (1995). Moral and Political Essays, trans. and ed. by John M. Cooper \& J. R. Procope. Cambridge: Cambridge University Press.

Shaftesbury, A. A. C. (1963 [1900]). Characteristics of Men, Manners, Opinions, Times, etc., Robertson, John M., (ed.), 2 vols. Gloucerster: Peter Smith.

Spinoza, B. (1985). Ethics, in The Collected Works of Spinoza, trans. and ed. by Edwin Curley, vol. 1. Princeton, NJ: Princeton University Press.

Tave, S. (1960). The Amiable Humorist: A Study in the Comic Theory and Criticism of the Eighteenth and Early Nineteenth Centuries. Chicago, IL: Chicago University Press.

Theophrastus. (2004). Characters, ed. with introduction trans. and commentary by James Diggle. Cambridge: Cambridge University Press.

Verdon, J. (2001). Rire au Moyen Age. Paris: Perrin.

Vlastos, G. (1991). Socrates: Ironist and Moral Philosopher. Cambridge: Cambridge University Press. 